\title{
Carotenoid extraction from the gonad of the scallop Nodipecten nodosus (Linnaeus, 1758) (Bivalvia: Pectinidae)
}

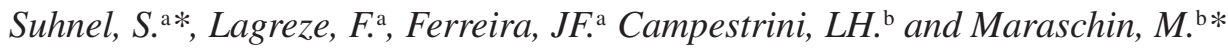 \\ ${ }^{a}$ Laboratório de Moluscos Marinhos, Universidade Federal de Santa Catarina - UFSC \\ Servidão dos Coroas, s/n, Barra da Lagoa, CEP 88061-600, Florianópolis, SC, Brazil \\ 'Laboratório de Morfogênese e Bioquímica Vegetal, \\ Universidade Federal de Santa Catarina - UFSC \\ Rod. Admar Gonzaga, 1346, Itacorubi, CEP 88040-900, Florianópolis, SC, Brazil \\ *e-mail: ssuhnel@gmail.com, m2@cca.ufsc.br
}

Received November 14, 2007 - Accepted March 12, 2008 - Distributed February 28, 2009

(With 2 figures)

\begin{abstract}
In marine bivalve mollusks, unsaturated molecules called carotenoids are present in the natural diet and play an important role in different biological process, especially in reproduction. In order to gain more insights into these compounds in Nodipecten nodosus it was necessary to develop a suitable protocol for extraction of carotenoids from the gonads. Female gonads of cultured scallops ( $75 \mathrm{~mm}$ length) were lyophilized and macerated in liquid $\mathrm{N}_{2}$. To verify the effect of composition in organosolvents on the extracting solutions, two organic solvents were tested: acetone and hexane $(\mathrm{Ac}=\mathrm{O}: \mathrm{Hex})$ at four ratios, 1:1, 1:3, 1:5, and 2:3, in four static extraction times: 0, 5, 10, and 15 minutes. Total carotenoids and astaxanthin contents were determined in the crude extracts by UV-visible spectrophotometry and high performance liquid chromatography (HPLC), respectively. Triplicate aliquots of $50 \mathrm{mg}$ were used for each treatment. The results indicated that the best single extraction $(0.312 \pm 0.016 \mu \mathrm{g}$ carotenoids $/ \mathrm{mg})$ was attained with $\mathrm{Ac}=\mathrm{O}$ : Hex 1:3, for 15 minutes. Through exhaustive extraction methodology (10x), a superior yield $(0.41 \pm 0.001 \mu \mathrm{g}$ carotenoids $/ \mathrm{mg}$ ) was obtained from a gonad sample in comparison to the highest value found for a single extraction. Astaxanthin content was reduced by $8.6 \%$ in carotenoid extract preservation assay, i.e., $-18{ }^{\circ} \mathrm{C}, 26$ days incubation, under $\mathrm{N}_{2}$ atmosphere.
\end{abstract}

Keywords: carotenoids, Nodipecten nodosus, extraction, organic solvents, scallop.

\section{Extração de carotenóides da gônada da vieira Nodipecten nodosus (Bivalvia: Pectinidae)}

\section{Resumo}

Em moluscos bivalves marinhos, carotenóides insaturados estão presentes na dieta natural, com um importante papel em diversos processos biológicos, em especial na reprodução. A elucidação dos efeitos destes compostos em Nodipecten nodosus requer o desenvolvimento de um protocolo adequado para a extração de carotenóides das gônadas desses animais. Para isso, gônadas de vieiras cultivadas ( $75 \mathrm{~mm}$ de comprimento) foram liofilizadas e maceradas em $\mathrm{N}_{2}$ líquido. Amostras em triplicata com $50 \mathrm{mg}$ foram coletadas para a utilização em cada tratamento. Os conteúdos de carotenóides totais e astaxantina foram determinados via espectrofotometria de luz UV-visível e cromatografia líquida de alta eficiência (CLAE), respectivamente. O efeito da composição em organosolventes das soluções de extração foi testado utilizando-se acetona $(\mathrm{Ac}=\mathrm{O})$ e hexano $(\mathrm{Hex})$ em quatro proporções $(\mathrm{Ac}=\mathrm{O}: \mathrm{Hex})$ : 1:1, 1:3, 1:5, e 2:3; em quatro tempos de extração: $0,5,10$, e 15 minutos. Os resultados mostraram que o melhor rendimento de extração $(0,312 \pm 0,016 \mu \mathrm{g}$ carotenóides $/ \mathrm{mg})$ foi obtido com Ac = O:Hex, 1:3, por 15 minutos. Com a utilização de protocolo de extração exaustiva (10x), uma quantidade superior $(0,41 \pm 0,001 \mu \mathrm{g}$ de carotenóides/mg) foi obtida de amostras de gônada, comparativamente aos valores obtidos em extrações únicas. O conteúdo de astaxantina foi reduzido em 8,6\% em testes de preservação deste metabólito em extratos crus $\left(-18{ }^{\circ} \mathrm{C}, 26\right.$ dias de incubação em atmosfera de $\left.\mathrm{N}_{2}\right)$.

Palavras-chave: carotenóides, Nodipecten nodosus, extração, solventes orgânicos, vieiras.

\section{Introduction}

Scallops are bivalve mollusks of the Pectinidae family that are economically important in aquaculture. According to FAO (2005), scallop world production reached 1.27 million metric tones in 2005, with China as the major producer ( $81 \%$ of the world production).
In aquatic organisms, particularly in mollusks, carotenoids are responsible for tissue pigmentation (Meyers, 1994). In addition, some carotenoids are vitamin A precursors (Miki et al., 1982; Farías-Molina, 2001) and are fundamental to the growth and maturation of gonads and 
by increasing fertilization. The fecundity rate plays an important role in embryonic development and hatching (Petit et al., 1991; Olson, 1993; Menasveta et al., 1994; Mantiri et al., 1995; Farías-Molina, 2001), optimizing larval feasibility and olfactory perception and chemoreception (Farías-Molina, 2001). They are also effective photo-protectors against UV radiation and, due to their anti-oxidant action (Miki, 1991; Miki et al., 1994; Farías-Molina, 2001), enhance tolerance to environmental stress, such as high concentrations of ammonia or low oxygen concentrations (Tacon, 1981; Torrissen, 1984; Menasveta et al., 1995; Olson and Owens, 1998). Furthermore, they also stimulate cellular growth and $\mathrm{Ca}^{2+}$ transportation through the cell membrane (FaríasMolina 2001), and have also been recognized as immunostimulant substances (Liñan-cabelo et al. 2002; Cuzon et al., 2004).

Studies to evaluate the influence of carotenoids in mollusk reproduction are strongly important, in special in scallops where these compounds help the immunological system (Schleder, 2007), the reproductive maturation and provide gametes with energy to the larvae development. Due to a disconnection between the natural reproductive cycle and the best period for hatchery production of larvae and seeds, in our case, for Nodipecten nodosus, laboratory maturation is a fundamental factor to the success of the commercial production, and carotenoids play an important role in this process.

Carotenoids are a family of natural compounds where the structural variations (chemo-diversity) are described and characterized from bacteria, algae, fungi and superior plants, and the photosynthesizing organisms are responsible for their biosynthesis (Rodriguez-Amaya, et al., 1984).

Carotenoids are cyclic or noncyclic tetraterpenes with properties and activities in biological systems related to their structures. In the biosynthesis pathway, acetyl$\mathrm{CoA}$ is the precursor, and two intermediate compounds are formed: mevalonic acid and its pyrophosphate form. Both originate from the basic structural unit of these metabolites, constituted by five-carbon $\left(\mathrm{C}_{5} \mathrm{H}_{8}\right)$ isoprene units (Rodriguez-Amaya, 2001). The isoprene units are assembled "head-to-tail", except in the central position of the resulting compound, which is "tail-to-tail", producing a symmetric structure with reversion of the symmetry plan at the centre of the molecule (RodriguezAmaya, 1984; Rodrigues-Amaya, 1997; Padula, 1999; Rodriguez-Amaya, 2001). They are highly unsaturated molecules which are subject to oxidation, as the polyene chains responsible for the special and desired properties of the carotenoids are also responsible for such instability (Hosang, 2001).

Analytical methods for the study of carotenoids include basically the preparation of the sample, organic solvent extraction, identification and quantification of these metabolites. Special precautions are necessary during the extraction procedure as regards oxidant agents, e.g., $\mathrm{O}_{2}$ and its reactive species (ROS) and light.
Carotenoids extracts should be stored in the dark under $\mathrm{N}_{2}$ atmosphere (Oliver and Palou, 2000).

The most commonly used techniques for carotenoids detection are UV-visible spectrophotometry, mass spectrometry and hydrogen or carbon nuclear magnetic resonance spectroscopy $\left({ }^{1} \mathrm{H}-\mathrm{NMR},{ }^{13} \mathrm{C}-\mathrm{NMR}\right)$, coupled or not with chromatographic techniques (RodriguezAmaya, 2001; Schoefs, 2002). Regardless of the technique utilized, carotenoid extraction is highly influenced by procedural variables such as type of sample, type and ratio of solvents, time of extraction, storage conditions, etc. Thus, taking into account the possibility of usage of several analytical techniques, the comparison of results should be done with precaution as they may not be precise.

Miki et al. (1982) extracted carotenoids from the gonads of four species of scallops, i.e., Chlamys nipponensis akazara, Pecten albicans, Chlamys nobilis, and Patinopecten yessoensis. The procedure included extraction with acetone, followed by drying the samples with anhydrous sodium sulfate. The extract was concentrated under low pressure (rotary evaporator), partitioned in a liquid-liquid chromatographic system (benzene:water, $1: 1)$ and recovered in the organic fraction. Carotenoids were determined by thin-layer chromatography using acetone:benzene (1:9) and dichloromethane:ethyl acetate $(4: 1)$ as mobile phases, sequentially. Pectenolone, pectenoxanthin, pectenol, astaxanthin and tetrol were identified in the carotenoid fraction. Quantitatively, the Chlamys nipponensis akazara scallop presented the highest concentration of these secondary metabolites.

Escarria et al. (1989) extracted carotenoids from fresh Argopecten circularis scallop gonads with petroleum ether:acetone:water $(6: 3: 1)$, followed by saponification of the extracts. Carotenoids determination was done by column chromatography (CC) and thin-layer chromatography (TLC) on silica gel with chloroform:ethyl acetate $(4: 1)$ as the mobile phase. The results revealed lutein and astaxanthin as major carotenoids in the gonads of this species.

Similarly, Viarengo et al. (1995) exhaustively extracted $(5 \mathrm{x})$ carotenoids from fresh tissue of gills and digestive glands of Adamussium colbecki and Pecten jacobaeus with acetone and petroleum ether. Total carotenoids were determined spectrophotometrically at $451 \mathrm{~nm}$ wavelength. The carotenoid yields in gills $(0.005 \mu \mathrm{g}$ carotenoids $/ \mathrm{mg})$ and digestive glands $(0.813 \mu \mathrm{g}$ carotenoids/mg) were higher in Adamussium colbecki than in Pecten jacobaeus (gills: $0.262 \mu \mathrm{g}$ carotenoids/mg, digestive glands: $0.454 \mu \mathrm{g}$ carotenoids $/ \mathrm{mg}$ ).

Sachindra et al. (2006) analyzed carotenoid contents from shrimp waste with hexane, petroleum ether, acetone, ethyl methyl ketone, ethyl acetate, isopropyl alcohol (IPA), ethanol, and methanol. Mixtures of acetone:hexane (50:50) and IPA:hexane (50:50) were also used. The carotenoid extracts in petroleum ether, hexane, acetone:hexane (50:50), and IPA:hexane (50:50) were directly treated with saline solution, anhydrous 
sodium sulphate, and concentrated (rotary evaporator, $40{ }^{\circ} \mathrm{C}$ ). The absorbances of the resulting carotenoid extracts were measured at $468 \mathrm{~nm}$ wavelength. The highest carotenoid yield was obtained with IPA:hexane (50:50, $0.043 \mu \mathrm{g}$ carotenoids/mg). IPA, hexane and acetone yields were of $0.040 \mu \mathrm{g} / \mathrm{mg}, 0.013 \mu \mathrm{g}$ carotenoids $/ \mathrm{mg}$, and $0.040 \mu \mathrm{g}$ carotenoids $/ \mathrm{mg}$, respectively.

Thus, taking into account the effect of several variables, i.e., methodology of extraction and analytical technique, based on the carotenoid content of a given biological sample in connection with studies on the Nodipecten nodosus scallop's reproductive biology, the present investigation aimed at determining the carotenoids content and the effect of composition in organic solvents of extracting mixtures on the carotenoid yield of $N$. nodosus scallop gonads. Furthermore, an exhaustive extraction protocol for these pigments was established, and the analysis of the stability of astaxanthin in carotenoid extracts was assayed over a 26-day-long experiment, under controlled storage conditions.

\section{Material and Methods}

\subsection{Sample preparation}

Fifteen scallops (75 mm height, 18 months old), cultured in longlines at $2 \mathrm{~m}$ depth, were collected at Porto Belo - SC (latitude $27^{\circ} 11^{\prime}$ '52.96" S and longitude $\left.48^{\circ} 30^{\prime} 39.58^{\prime} \mathrm{W}\right)$. The scallops were immediately transported with valves shut in expanded polystyrene boxes to the laboratory. The female portions of the gonads were removed with the aid of scissors and scalpel. Salt was removed by washing the gonads with ammonium formiate $(0.5 \mathrm{M})$. The gonads were dried with filter paper, weighed (Kern scale $430-21)$, frozen $\left(-18^{\circ} \mathrm{C}, 24\right.$ hours), lyophilized and weighed again.

The lyophilized gonads (6.44 g, total dry weight) were pooled, ground up using a mortar and pestle, and stored at $-18{ }^{\circ} \mathrm{C}$ in an amber flask filled with $\mathrm{N}_{2}$ for later carotenoid extraction.

\subsection{Carotenoid extraction - effect of composition in organic solvents of the extracting solution}

Four extracting mixtures of acetone $(\mathrm{Ac}=\mathrm{O}$, analytical grade) and n-hexane (Hex, analytical grade) were tested at the ratios (v/v) of 1:1, 1:3, 1:5, and 2:3. Additionally, four incubation times (minutes) of the samples in these extracting solutions were tested: $\mathrm{t}_{0}, \mathrm{t}_{5}, \mathrm{t}_{10}$ and $\mathrm{t}_{15}$. In $\mathrm{t}_{0}$, the samples were immersed in solvent mixture, removed immediately, and filtered on filter paper. The carotenoid yield was then determined. Samples of $50 \mathrm{mg}$ (dry weight) were transferred to $40 \mathrm{~mL}$ beakers added with $5 \mathrm{~mL}$ solvent mixture and wrapped with aluminum foil. The samples were constantly agitated (Sisatom magnetic agitator) according to the time of incubation, protected from light at room temperature $\left(23^{\circ} \mathrm{C}\right)$. After extraction, the samples were filtered on filter paper, their volume was made up to $3 \mathrm{~mL}$, and they were stored in an amber flask $(\sim 10 \mathrm{~mL})$ filled with $\mathrm{N}_{2}$. These samples were kept frozen $\left(-18^{\circ} \mathrm{C}\right)$ for further total carotenoid determination in an UV-visible spectrophotometer (Hitachi, model U-1800).

\subsection{Carotenoids extraction - determination of exhaustive extraction protocol}

After determining the most efficient solvent mixture $(\mathrm{Ac}=\mathrm{O}: \mathrm{Hex} ; 1: 3)$, exhaustive extraction of the pigments was performed. Samples of $50 \mathrm{mg}$ were transferred to $40 \mathrm{~mL}$ beakers and homogenized with $5 \mathrm{~mL}$ of solvent mixture (Ac $=\mathrm{O}:$ Hex 1:3) and then agitated (5 minutes, Sisatom magnetic agitator). The extract was filtered through cellulose under vacuum and the residue was repeatedly extracted $(10 \mathrm{x})$ with a $5 \mathrm{~mL}$ solvent mixture. The carotenoid extracts were made up to $3 \mathrm{~mL}$, transferred to amber flasks filled with $\mathrm{N}_{2}$, and frozen $\left(-18{ }^{\circ} \mathrm{C}\right)$ for further carotenoid quantitation.

\subsection{Total carotenoid quantification}

To determine the amount of total carotenoids extracted, UV-visible spectrophotometry (Hitachi, U-1800) was used for a spectral window between 380 and $750 \mathrm{~nm}$, in triplicate. Carotenoid concentration was obtained using the Lambert-Beer law and for calculation purposes the following equation was applied to the absorbance values:

Total carotenoid $(\mu \mathrm{g} / \mathrm{mg})=$

(absorbance / $\varepsilon$ x molecular mass x $1000 \mathrm{x}$ sample volume $(\mathrm{mL})$ ) (sample dry weight $(\mathrm{mg})$ )

The specific optical extinction coefficient $\varepsilon_{1 \mathrm{~cm}}^{1}$ of $124000_{\text {(astaxanthin) }}$ at $460 \mathrm{~nm}$ was used (Buchwaldt andJencks, 1968) in conjunction with a molecular mass of 596.84 (astaxanthin). Absorbance measurements were performed in triplicate and the values previously averaged were applied in the above equation (MínguezMosquera et al., 2002).

\subsection{Stability of astaxanthin in carotenoid extract during storage}

For purpose of analysis of the astaxanthin stability in carotenoid extract during a 26 day long storage period, gonads $(n=3)$ were pooled and the pigments extracted. The carotenoid extraction procedure considered the incubation of the samples (50 mg dry weight) in a $\mathrm{Ac}=\mathrm{O}: \mathrm{Hex}(1: 3)$ solvent mixture for 15 minutes. Carotenoids were recovered by filtration through cellulose under vacuum, stored at $-18{ }^{\circ} \mathrm{C}$ in amber flasks with $\mathrm{N}_{2}$. Astaxanthin content was determined in the carotenoid extracts through HPLC immediately after extraction $\left(\mathrm{t}_{0}\right.$ day) and 26 days after storage $\left(\mathrm{t}_{26}\right.$ day).

\subsection{HPLC determination of astaxanthin}

Aliquots $(300 \mu \mathrm{L})$ of the carotenoid extract were collected and filtered $(0.22 \mu \mathrm{m})$. Samples $(10 \mu \mathrm{L})$ were injected into a liquid chromatograph (Shimadzu LC$10 \mathrm{~A})$ coupled to a thermostatized $\left(40{ }^{\circ} \mathrm{C}\right) \mathrm{C}_{18}$ reverse phase column (Vydac - BioRad, $250 \times 4.6 \mathrm{~mm} \varnothing$ ) and 
UV-visible detector $(\lambda=460 \mathrm{~nm})$. Mobile phase was acetonitrile:methanol (90:10, HPLC grade) at a flow rate of $0.8 \mathrm{~mL} / \mathrm{min}$.

Astaxanthin identification was carried out by comparing the internal standard $\left(0.461 \mathrm{mg} .10 \mathrm{~mL}^{-1} \mathrm{Hex}\right.$, Sigma - MO, USA) retention time under the same experimental conditions. Quantification was done by calculating the integrals of the areas under the corresponding peaks and external standard curve $(y=7044.96 x$, $\left.r^{2}=0.994\right)$

\subsection{Statistical analysis}

Total carotenoid concentrations were submitted to analysis of variance (ANOVA) and LSD test, assuming a significance level of 5\%. Additionally, data from the time of incubation and exhaustive extraction were submitted to regression analysis. The analyses were performed using the statistical program SPSS (version 13.0).

\section{Results}

For the extractions, scallop Nodipecten nodosus gonads were lyophilized and the mean water content of the fresh samples was $80 \pm 1.6 \%$.

\subsection{Carotenoids extraction - effect of composition in organic solvents of the extracting solution}

The total amounts of carotenoids extracted from the female portions of the scallops' gonads using the solvent mixtures are presented in Table 1.

The $\mathrm{Ac}=\mathrm{O}:$ Hex mixture at the $1: 3(\mathrm{v} / \mathrm{v})$ ratio provided the best carotenoid yield $(\mathrm{p}<0.05)$ despite the incubation time tested. When compared to $\mathrm{t}_{0}(0.184 \mu \mathrm{g}$ carotenoids $/ \mathrm{mg}$ ), carotenoid yields increased by $19.0 \%$ $\left(\mathrm{t}_{5}\right), 41.3 \%\left(\mathrm{t}_{10}\right)$ and $69.9 \%\left(\mathrm{t}_{15}\right)$ for this mixture (Table 1$)$. In fact, the mixture demonstrated that it was able to afford satisfactory extraction of the secondary metabolites, even under virtually unsuitable extraction conditions, i.e., brief contact between sample and mixture $\left(\mathrm{t}_{0}\right)$. Such approaches are interesting when one is seeking procedures that allow quick and sound screening of samples as sources of carotenoids. In addition, the results of long incubation $\left(\mathrm{t}_{15}\right)$ suggest that scallop $N$. nodosus gonads are carotenoid-rich $(0.312 \pm 0.016 \mu$ g carotenoids $/ \mathrm{mg})$, which is relevant in the biochemical and nutritional contexts, as well as in the management of scallop reproduction.

The analysis of the dynamics of carotenoid extraction over the incubation times (Figure 1a, b, c, and d) revealed a continuous increase in the concentration of these metabolites for all the solvent mixtures tested. At the end of the experimental period $\left(t_{15}\right)$, carotenoids concentration did not tend to reduce, independent of the mixture ratio of the solvents. This finding indicated that the carotenoids from samples were not completely extracted and that the extracting solvent was not saturated. Interestingly, the Ac $=\mathrm{O}: \mathrm{Hex}$ mixtures at 1:5, 1:1 and $2: 3$ were not significantly different from $t_{15}$.

Carotenoid concentration increased with time of incubation for all the extraction solutions and the values found for the $\mathrm{Ac}=\mathrm{O}: \mathrm{Hex}$ mixture in the ratios $1: 3$ and $2: 3$ differed significantly $(\mathrm{p}<0.05)$ in $\mathrm{t}_{15}$ from their values in $\mathrm{t}_{0}, \mathrm{t}_{5}$ and $\mathrm{t}_{10}$. Contrarily, the carotenoid yields in $\mathrm{t}_{15}$ were similar to those in $\mathrm{t}_{10}$ for the mixtures $\mathrm{Ac}=\mathrm{O}: \mathrm{Hex}$ $1: 1$ and $1: 5$ as distinct values $(\mathrm{p}<0.05)$ were found in comparison to $\mathrm{t}_{0}$ (Table 1). The Ac $=\mathrm{O}:$ Hex mixtures at 1:5, 1:1 and 2:3 were not significantly different.

The regression analysis of the carotenoid content of female gonads of scallop $N$. nodosus and the extraction times for the Ac $=\mathrm{O}:$ Hex mixtures at $1: 3$ and 2:3 revealed a linear relationship $\left(r^{2} 0.998\right)$ for the variables studied (Figure 1b, d). A quadratic model, however, seemed to be more suitable to explain the relation between variables when using the $\mathrm{Ac}=\mathrm{O}:$ Hex mixtures

Table 1. Total carotenoids $\left(\mu \mathrm{g} . \mathrm{mg}^{-1}\right)$ extracted from the lyophilized scallop Nodipecten nodosus female gonads according to the extraction solution and incubation time treatments.

\begin{tabular}{|c|c|c|c|}
\hline & Incubation time & & Incubation time \\
\hline \multirow[t]{2}{*}{$\begin{array}{c}\text { Extraction } \\
\text { solution (a:h) }\end{array}$} & $\begin{array}{c}\text { Total carotenoids } \\
\left(\mu{\left.\mathrm{g} . \mathrm{mg}^{-1}\right)}\right.\end{array}$ & \multirow[t]{2}{*}{$\begin{array}{c}\text { Extraction } \\
\text { solution (a:h) }\end{array}$} & $\begin{array}{c}\text { Total carotenoids } \\
\left(\mu \mathrm{g}^{\left.-\mathrm{mg}^{-1}\right)}\right.\end{array}$ \\
\hline & 0 minute $\left(t_{0}\right)$ & & 5 minutes $\left(t_{5}\right)$ \\
\hline $1: 1$ & $0.125^{(\mathrm{a}) \dagger(\mathrm{A})} \pm 0.006$ & $1: 1$ & $0.200^{(\mathrm{a})(\mathrm{B})} \pm 0.015$ \\
\hline $1: 3$ & $0.184^{(\mathrm{b})(\mathrm{A})} \pm 0.004$ & $1: 3$ & $0.219^{(\mathrm{a})(\mathrm{B})} \pm 0.021$ \\
\hline $1: 5$ & $0.105^{(\mathrm{c})(\mathrm{A})} \pm 0.010$ & $1: 5$ & $0.185^{\text {(ac) (B) }} \pm 0.025$ \\
\hline $2: 3$ & $0.125^{(\mathrm{ac})(\mathrm{A})} \pm 0.012$ & $2: 3$ & $0.170^{(\mathrm{bc})(\mathrm{B})} \pm 0.003$ \\
\hline \multicolumn{3}{|c|}{10 minutes $\left(t_{10}\right)$} & 15 minutes $\left(t_{15}\right)$ \\
\hline $1: 1$ & $0.213^{(\mathrm{a})(\mathrm{BC})} \pm 0.016$ & $1: 1$ & $0.236^{(\mathrm{a})(\mathrm{C})} \pm 0.014$ \\
\hline $1: 3$ & $0.260^{(\mathrm{b})(\mathrm{B})} \pm 0.020$ & $1: 3$ & $0.312^{(\mathrm{b})(\mathrm{C})} \pm 0.016$ \\
\hline $1: 5$ & $0.218^{(\mathrm{a})(\mathrm{BC})} \pm 0.015$ & $1: 5$ & $0.244^{(\mathrm{a})(\mathrm{C})} \pm 0.015$ \\
\hline $2: 3$ & $0.222^{\text {(a) }(\mathrm{C})} \pm 0.013$ & $2: 3$ & $0.265^{(\mathrm{a})(\mathrm{D})} \pm 0.015$ \\
\hline
\end{tabular}

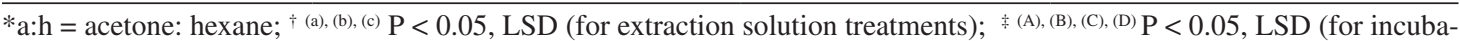
tion time treatments). 
at 1:5 and $1: 1$, with $r^{2} 0.997$ and $r^{2} 0.986$, respectively (Figure 1a, c).

\subsection{Carotenoid extraction - determination of exhaustive extraction protocol}

Considering that a single extraction of a compound or class of compounds can lead, in many cases, to underestimation, the effect of repeated extractions of carotenoids (exhaustive extraction) was assessed in scallop Nodipecten nodosus gonads. The exhaustive extraction procedure adopted the organic solvent mixture of $\mathrm{Ac}=\mathrm{O}:$ Hex 1:3 because highest carotenoid yields were afforded as previously described (Table 1).

With the exhaustive extraction methodology $0.410 \pm$ $0.001 \mu \mathrm{g}$ carotenoids/mg sample were extracted from a gonad sample after 10 extractions, a superior performance as compared to the single extraction treatment $0.312 \pm 0.016 \mu \mathrm{g}$ carotenoids $/ \mathrm{mg}$ sample at $\mathrm{t}_{15}$.

The analysis of carotenoid concentration throughout the exhaustive extraction procedure revealed that the highest yields occurred in the first stage of extraction

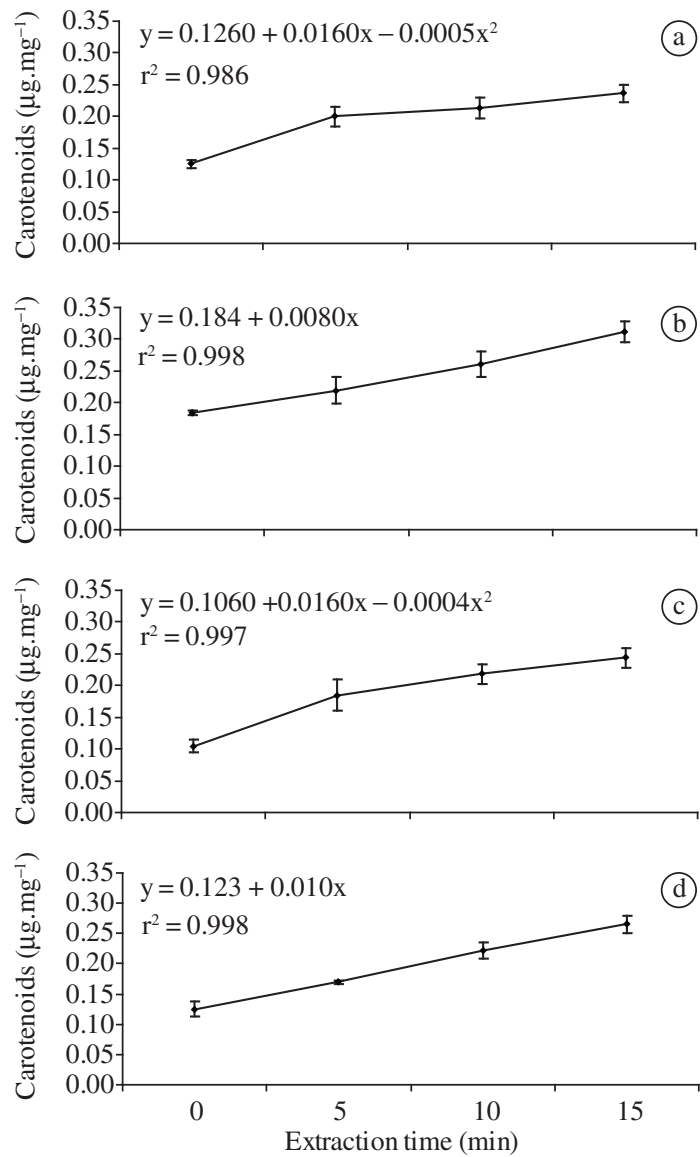

Figure 1. Total carotenoids $\left(\mu \mathrm{g} . \mathrm{mg}^{-1}\right)$ extracted from female gonads of scallop Nodipecten nodosus, according to the acetone $(\mathrm{Ac}=\mathrm{O})$ :hexane $(\mathrm{Hex})$ ratio in the extracting solutions and the extraction times. Ac = O:Hex: (a) 1:1, (b) 1:3, (c) $1: 5$, and (d) 2:3.
$(0.223 \pm 0.001 \mu \mathrm{g}$ carotenoids/mg; 5 minutes incubation). Subsequent extractions showed lower carotenoid yields as presented in Figure 2, and from the sixth extraction concentrations tended to stabilize at about $0.014 \mu \mathrm{g}$ carotenoids/mg. In addition, it is worth mentioning the similarity found between the values for total content of the pigments under study for the first three extractions (0.308 $\mu \mathrm{g}$ carotenoids $/ \mathrm{mg}$ ) as compared to a single 15 minute long extraction $(0.312 \mu$ g carotenoids $/ \mathrm{mg})$. On the other hand, through the exhaustive extraction methodology (10x), a superior yield $(0.410 \pm 0.001 \mu \mathrm{g}$ carotenoids $/ \mathrm{mg}$ ) was obtained from a gonad sample in comparison to the highest value found for a single extraction, i.e., $0.312 \pm 0.016 \mu \mathrm{g}$ carotenoids $/ \mathrm{mg}$ at $\mathrm{t}_{15}$. Exhaustive extraction protocols are tedious and time-consuming and obviously are not suitable for the aim of quickly evaluating the potential of a given biomass sample as a source of compounds of interest. On the other hand, such an approach seems to be useful for a more detailed analysis of the effects of secondary metabolites (i.e., carotenoids) in the reproductive biology and ecological interactions of species.

\subsection{Stability of carotenoid extracts}

Carotenoids are compounds which are subject to degradation by environmental factors such as temperature, light radiation and oxidizing agents, thus requiring adequate storage. After 26 days of storage, the astaxanthin content was reduced by $8.6 \%$, from $32.55 \pm 0.60 \mu \mathrm{g}$ carotenoids $/ \mathrm{mL}$ at $\mathrm{t}_{0}$, to a final $29.74 \pm 1.69 \mu \mathrm{g}$ carotenoids/mL.

\section{Discussion}

The definition of practical and profitable methods to extract carotenoids from scallop gonad is of importance to future studies about the influence of these compounds in mollusk reproduction, in special for Nodipecten nodosus production where it is necessary to proceed to hatchery maturation to obtain larvae and seeds for commercial productions.

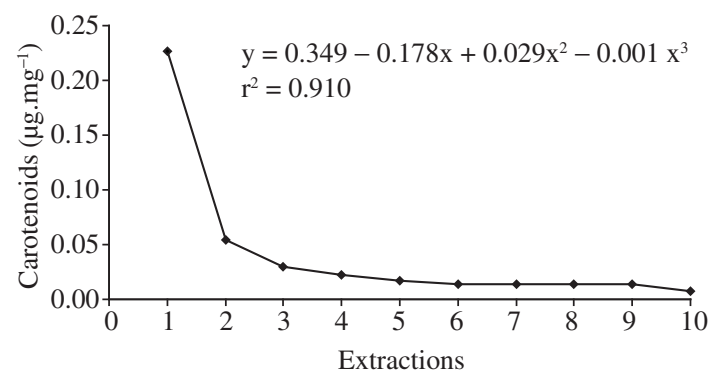

Figure 2. Exhaustive extraction of total carotenoid content $\left(\mu \mathrm{g} \cdot \mathrm{mg}^{-1}\right)$ of female gonad samples of scallop Nodipecten nodosus following a sequential extraction protocol (10x) with $\mathrm{Ac}=\mathrm{O}: \mathrm{Hex}(1: 3)$ extracting solution. 
In this study, the maximum carotenoid yield $(0.312 \mu \mathrm{g}$ carotenoids $/ \mathrm{mg})$ found in lyophilized gonads of the scallop Nodipecten nodosus was higher than the yield obtained by Miki et al. (1982) from fresh gonads of the scallops Patinopecten yessoensis $(0.0156 \mu \mathrm{g}$ carotenoids/mg), Chlamys nipponensis akazara $(0.0715 \mu \mathrm{g}$ carotenoids $/ \mathrm{mg})$, Chlamys nobilis $(0.0360 \mu \mathrm{g}$ carotenoids/ $\mathrm{mg})$, and Pecten albicans $(0.0578 \mu \mathrm{g}$ carotenoids/mg) and by Escarria et al. (1989) for Argopecten circularis $(0.00002 \mu \mathrm{g}$ carotenoids/mg). However, care should be taken in the comparison of these results with the findings herein described since the scallop samples are of different species and the tissues used by those authors were not lyophilized ones.

Lyophilization helps in sample preservation because water content is meaningfully reduced. Additionally, in extraction procedures for non-polar compounds, i.e., carotenoids, lyophilized samples allows to obtain higher yields by minimizing the effect of water to repulse the organic solvents.

Several organic solvent mixtures have been used to extract carotenoids from gonads of mollusks and crustaceans, as observed for the scallops Patinopecten yessoensis, Chlamys nipponensis akazara, Chlamys nobilis and Pecten albicans. Miki et al. (1982) used acetone for carotenoid extraction from fresh gonads, whereas a mixture of acetone, petroleum ether and water (6:3:1) was used in samples of scallop Argopecten circularis (Escarrina et al., 1989). As mentioned above, the carotenoid concentrations found by these authors were lower than those observed in this study, indicating a superior performance of the $\mathrm{Ac}=\mathrm{O}: \mathrm{Hex}$ mixtures used.

Similarly, acetone was used in carotenoid extraction procedures for shrimp waste (Sachindra et al., 2005; Sachindra et al., 2006). Sachindra et al. (2006) found a higher carotenoid yield $(0.040 \mu \mathrm{g}$ carotenoids/ $\mathrm{mg}$ shrimp waste) using acetone than using hexane (0.013 $\mu \mathrm{g}$ carotenoids/mg shrimp waste). The yield of $0.038 \mu \mathrm{g}$ carotenoids/mg shrimp waste using a 1:1 mixture of these two solvents was similar to that when hexane alone was used.

A meaningful issue for optimization of extraction protocols regards the chemical composition of the sample to be extracted, since it directly influences the choice of the organic solvent and the yield. For the scallop Nodipecten nodosus, Lodeiros et al. (2001) measured total lipids, total protein and total carbohydrates in cultured scallop gonads during different seasons of the year. They found $160 \mathrm{mg} \cdot \mathrm{g}^{-1}$ (dry weight) of total lipids, $400 \mathrm{mg} \cdot \mathrm{g}^{-1}$ (dry weight) of total protein and $80 \mathrm{mg} \cdot \mathrm{g}^{-1}$ (dry weight) of carbohydrates. Assessing these results, the presence of lipids in the gonads is notable when hexane, a non-polar organic solvent, leads the carotenoid extraction together with acetone. In fact, studying the carotenoid yields with the different $\mathrm{Ac}=\mathrm{O}: \mathrm{Hex}$ ratios, higher yields were found for the mixture at $1: 3$ than for $1: 1,1: 5$ and $2: 3$, revealing a better interaction for the purpose of carotenoid extraction between the scallop $N$. nodosus gonads, a chemi- cally complex matrix, and the former extraction solution. Thus, taking into consideration the diversity of chemical composition of a set of biological samples under study and the great number of combinations of organosolvents for carotenoid extraction, one should be aware of the need to establish dedicated protocols in order to optimize the extraction yield of the secondary metabolites herein described.

In a second experiment, an exhaustive extraction protocol was used to totally extract carotenoids from scallop gonads. The highest yield was obtained at the first moment of extraction since the content of the pigments tended to stabilize, ca. $0.014 \mu \mathrm{g}$ carotenoids/mg after the fifth extraction. In spite of being a time-consuming task, exhaustive extraction seemed to produce a more realistic result of total carotenoid content $(0.410 \pm$ $0.001 \mu \mathrm{g}$ carotenoids $/ \mathrm{mg}$ ) of the samples under study in comparison to the highest value found for a single extraction $\left(0.312 \pm 0.016 \mu \mathrm{g}\right.$ carotenoids $\left./ \mathrm{mg}, \mathrm{t}_{15}\right)$. On the other hand, for fast quantification of these pigments in female gonads of $N$. nodosus scallops, extraction with 15 minutes incubation using $\mathrm{Ac}=\mathrm{O}: \mathrm{Hex}$ (1:3) solutions proved to be an efficient method. Finally, in the carotenoid extracts preservation analysis, the small reduction in astaxanthin content ( $0.3 \%$ per day) after 26 days' storage suggests that the proposed methodology is effective and useful when the analytical capacity is below demand.

The results obtained provide a suitable methodology to extract and analyze the carotenoids from the scallop Nodipecten nodosus. Such an approach is of interest in, for example, experiments aiming at to study the influence of these secondary metabolites on reproduction system of that species and also to improve the hatchery maturation of this specie for commercial production of larvae and seeds.

Acknowledgements - We are thankful to FINEP for financial support and to CAPES/UFSC for a doctorate scholarship.

\section{References}

BUCHWALDT, M. and JENCKS, WP., 1968. Optical Properties of Astaxanthin Solutions and Aggregates. Biochemistry, vol. 7, no. 2, p. 834-843.

CUZON, G., LAWRENCE, A., GAXIOLA, G., ROSAS, C. and GUILLAUME, J., 2004. Nutrition of Litopenaeus vannamei reared in tanks or in ponds. Aquaculture, vol. 235, no. 1-4, p. 513-551.

ESCARRIA, S., REYES, C. and ROHAN, D., 1989. Estudio bioquímico de la escalopa Argopecten circularis. Ciencias Marinas, vol. 15, no. 1, p.63-72.

FAO, 2005. Global Aquaculture Production 1950-2005. Available from: <http:www.fao.org>. Access: 29 May, 2007.

FARÍAS-MOLINA, A., 2001. Nutrición en moluscos Pectínidos. In MAEDA-MARTINZ, A.N. Los Moluscos Pectínidos de Iberoamérica. Ciencia y Acuicultura. México: Ed. Limusa, p. 89-104. 
HOSANG, K., 2001. Extração de pigmentos carotenóides apartir de resíduos do processamento de camarões (Rarfantepenaeus paulensis). Florianópolis, Brazil: Universidade Federal de Santa Catarina. Master Thesis

LIÑAN-CABELLO, MA., PANIAGUA-MICHEL, JJ. and HOPKINS, PM., 2002. Bioactive roles of carotenoids and retinoids in crustaceans. Aquaculture Nutrition, vol. 8, no. 4, p. 299-309.

LODEIROS, CJ., RENGEL, JJ., GUDERLEY, HE., NUSETTI, O. and HILMMELMAN, JH., 2001. Biochemical composition and energy allocation in the tropical scallop Lyropecten (Nodipecten) nodosus during the months leading up to and following the development of gonads. Aquaculture, vol. 199, no. 1-2, p. 63-72.

MANTIRI, DM., NE`GRE-SADARGUES, G., CASTILLO, R. and TRILLES, JP., 1995. Evolution of carotenoid metabolic capabilities during the early development of the European lobster Homarus gammarus (Linneaus 1758). Comparative Biochemist and Physiology B, vol. 111, no. 4, p. 553-558.

MEYERS, PS., 1994. Developments in World aquaculture, feed formulation and role of carotenoids. Pure and Applied Chemistry, vol. 66, no. 5, p. 1069-1076.

MENASVETA,P.,CHOOSUWAP,J.,PIYATIRATITIVORAKUL, S., FAST, A. and LATSCHA, T., 1994. Effect of dietary astaxanthin on gonadal maturation and spawning of giant tiger prawn (Penaeus monodon fabricius). In: CHOU, LM., MUNRO, AD., LAM, TJ., CHEN, TW., CHEONG, LK., HOOI, KW., PHANG, VPE. and TAN, CH. (Eds). The Third Asian Fisheries Forum. Manila, Philippines: Asian Fisheries Society, p. 713-716.

\section{MENASVETA, P., CHAIYANETR, N.,} PIYATIRETITIVORAKUL, S. and KITTAKOOP, P., 1995. Dietary prophylaxis against yellow-head disease in black tiger shrimp (Penaeus monodon). Flegel, TW., Menasveta, P. and Paisarnrat, S. (Eds). In Shrimp Biotechnology in Thailand. Bangkok, Thailand: NSTA, p. 61-70.

MIKI, WN., YAMAGUCHI K. and KONOSU S., 1982. Comparison of carotenoids in the ovaries of marine fish and shellfish. Comparative Biochemistry and Physiology B, vol. 71, no. 1 , p. 7-11.

MIKI, W., 1991. Biological functions and activities of animal carotenoids. Pure Applied Chemistry, vol. 63, no. 1, p. 141-146.

MIKI, W., OTAKI, N., SHIMIDZU, N. and YOKOYAMA, A., 1994. Carotenoids as free radical scavengers in marine animals. Journal of Marine Biotechnology, vol. 2, no. 1, p. 35-37.

OLIVER, J. and PALOU, A., 2000. Chromatographic determination of carotenoids in food. Journal of Chromatography $A$, vol. 881 , no. $1-2$, p. 543-555.

OLSON, JA., 1993. Vitamin A and carotenoids as antioxidants in a physiological context. Journal of nutritional science and vitaminology, vol. 39, p. 57-65.
OLSON, VA. and OWENS, IP., 1998. Costly sexual signals: are carotenoids rare, risky or required? Trends in Ecology and Evolution, vol. 13, no. 12, p. 510-514.

PADULA, M., 1999. Degradação de -caroteno e cantaxantina em sistema-modelo de baixa umidade à temperatura ambiente. Formação de produtos não voláteis e voláteis. Campinas: UNICAMP. Dissertação de Mestrado.

PETIT, H., SANCE, S., NEGRE-SADARGUES, G., CASTILLO, R. and TRILLES, JP., 1991. Ontogeny of carotenoid metabolism in the prawn Penaeus japonicus Bate (1888) (Crustacea Peneidae). A qualitative Approach. Comparative Biochemistry and Physiology B, vol. 99, no. 3, p. 667-71.

RODRIGUEZ-AMAYA, DB., BOBBIO, FO. and BOBBIO, PA., 1984. Curso sobre pigmentos naturais. Campinas: SBCTAFEAA, UNICAMP.

RODRIGUEZ-AMAYA, DB., 1997. Carotenóides: estruturas, propriedades e funções. Ciência de Alimentos - Avanços e perspectivas na América Latina. Campinas, Brasil: Fundação Cargill, cap. 3, p. 20-31.

-, 2001. A guide to carotenoid analysis in foods. Washington, DC.: Ed. ILSI - International Life Sciences Institute.

SACHINDRA, NM., BHASKAR, N. and MAHENDRAKAR, NS., 2005. Carotenoids in crabs from marine and fresh waters of India. Lebens Wiss und-Technology - LWT - Food Science and Technology., vol. 38, no. 3, p. 221-225.

-, 2006. Recovery of carotenoids from shrimp waste in organic solvents. Waste Management, vol. 26, no. 10, p. 1092-1098.

SCHLEDER, DD., 2007. Estudo de alguns parâmetros hematoimunológicos no pectinídeo Nodipecten nodosus e da influência de uma suplementação de carotenóides na dieta, durante o período de reprodução induzida. Florianópolis, Santa Catarina, Brasil: UFSC. Dissertação de Mestrado

SCHOEFS, B., 2002. Chlorophyll and carotenoid analysis in food products. Properties of the pigments and methods of analysis. Trends in Food Science and Technology, vol. 13, no. 11 , p. $361-371$.

TACON, AG., 1981. Speculative review of possible carotenoid function in fish. Progressive Fish-Culturist, vol. 43, no. 44, p. 205-208.

TORRISSEN, O., 1984. Pigmentation of salmonids of carotenoids in eggs and start-feeding diet on survival and growth rate. Aquaculture, vol. 43, no. 1-3, p.185-193.

VIARENGO, A., CANESI, L., MARTINEZ, PG., PETERS, LD. and LIVINGSTONE, DR. 1995. Pro-oxidant processes and antioxidant defence systems in the tissues of the Antarctic scallop (Adamussium colbecki) compared with the Mediterranean scallop (Pecten jacobaeus). Comparative Biochemistry and Physiology B, vol. 111, no. 1, p. 119-126. 